\title{
Characterization and Performance Evaluation of Dye Sensitized Solar Cell Using Nanostructured $\mathrm{TiO}_{2}$ Electrode
}

\author{
Sule Erten-Ela \\ Solar Energy Institute, Ege University, Bornova, 35100 Izmir, Turkey \\ Correspondence should be addressed to Sule Erten-Ela; sule.erten@ege.edu.tr
}

Received 26 May 2013; Accepted 19 February 2014; Published 1 June 2014

Academic Editor: Vincenzo Augugliaro

Copyright (C) 2014 Sule Erten-Ela. This is an open access article distributed under the Creative Commons Attribution License, which permits unrestricted use, distribution, and reproduction in any medium, provided the original work is properly cited.

\begin{abstract}
Metal-free organic sensitizer consisting of donor, electron conducting, and anchoring anhydride groups was engineered at molecular level and synthesized. Dye sensitized solar cells based on conjugated naphthalene dye were fabricated using nanoporous electrode. Photoelectrodes with a $7 \mu \mathrm{m}$ thick nanoporous layer and a $5 \mu \mathrm{m}$ thick light-scattering layer were used to fabricate dye sensitized solar cells. DSSCs were fabricated in a $\mathrm{FTO} / \mathrm{nc}-\mathrm{TiO}_{2} /$ organic dye $/ \mathrm{I}^{-} / \mathrm{I}_{3}{ }^{-} / \mathrm{Pt} / \mathrm{FTO}$ device geometry. Dye sensitized solar cell was characterized by current density-voltage $(J-V)$ measurement. All current-voltage $(I-V)$ measurements were done under 100 $\mathrm{mW} / \mathrm{cm}^{2}$ light intensity and AM 1.5 conditions. The photovoltaic data revealed a short circuit photocurrent density of $1.86 \mathrm{~mA} / \mathrm{cm}^{2}$, an open circuit voltage of $430 \mathrm{mV}$, and a fill factor of 0.63 , corresponding to an overall conversion efficiency of $0.53 \%$.
\end{abstract}

\section{Introduction}

The demand for clean and environmentally friendly energy sources continues to increase due to depletion of conventional energy sources. One of the promising candidates of these new energy sources is solar energy, which is clean, renewable, and limitless. Dye sensitized solar cells have gained much more attention as one of the most promising energy harvesting devices since the report of ruthenium based photosensitizers in 1991 by O'Regan and Grätzel [1]. Ruthenium photosensitizers have shown high photoelectric conversion efficiencies of over $11 \%$ under AM 1.5 conditions [2]. Compared with them, metal-free organic dyes have advantages including lower cost, easier modification and purification, and environmental friendliness [1-3]

Generation of electrical energy from solar light is a long-term research interest and dye sensitized solar cells with a mesoporous $\mathrm{TiO}_{2}$ have been regarded as one of the most promising candidates among these regenerative energy sources [4-12]. Although the research activities in this field are spanning the range from devising novel semiconductor electrodes and solid state hole conductors [13], particular importance is the development of well performing dyes. Organometallic and metal-free organic dyes are requested to display broad light absorption capability, which can cover the whole solar light spectrum along with fast electron injection of electrons from photoexcited dyes to the conduction band (CB) of semiconductor electrodes and slow recombination between the injected electrons and resulting dye cations and/or $\mathrm{I}^{-} / \mathrm{I}_{3}{ }^{-}$redox couple. It is also crucial to design suitable binding groups as well as the spacer between the groups and dye core. Relative rate of electron injection is managed by the anchoring groups which are chemically adsorbed and attached to $\mathrm{TiO}_{2}$ electrode. The controllability reaches cell performance including short circuit current (Jsc), open circuit voltage (Voc), and overall conversion efficiency [1422].

Thin films of organic dyes with conjugated $\pi$-electron systems are widely used in electronic and optoelectronic devices such as organic light-emitting diodes or solar cells. Hybrid organic/inorganic materials are promising candidates in photovoltaic (PV) cells. There are several basic requirements guiding the molecular engineering of an efficient sensitizer. The excited state should match the energy of the conduction band edge of the oxide. Light excitation should be associated with vectorial electron flow from the light harvesting moiety of the dye towards the surface of the semiconductor surface providing for efficient electron 
transfer from the excited dye to the $\mathrm{TiO}_{2}$ conduction band, a strong conjugation across the donor and anchoring groups, and good electronic coupling between the lowest unoccupied orbital (LUMO) of the dye and the $\mathrm{TiO}_{2}$ conduction band. A major factor for the low conversion efficiency of many organic dyes in the DSSC is the formation of dye aggregates on the semiconductor surface. Such an aggregation phenomenon would affect the light absorption by filtering effect $[23,24]$. Therefore, for obtaining optimal performance, aggregation of organic dyes needs to be avoided through appropriate structural modification [24, 25].

Anhydride groups are easily attached to $\mathrm{TiO}_{2}$ electrode and it is very well known in the literature that these groups bound to $\mathrm{TiO}_{2}$ surface over dicarboxy forms with the opening anhydride ring. Monoanhydride groups are immobilized into $\mathrm{TiO}_{2}$ electrode to realize electron injection under illumination. Perylene monoanhydride derivatives are proven to present photovoltaic efficiencies in dye sensitized solar cells [4]. These results confirm the importance of anhydride structure.

In this paper, $\mathrm{N}, \mathrm{N}^{\prime}$-diphenylbenzene-1,4-diamino-1,8naphthalic anhydride (EE-1) has been synthesized to fabricate dye sensitized solar cells. $E_{\text {HOMO }}$ and $E_{\text {LUMO }}$ energy levels of conjugated naphthalene dye were calculated using cyclic voltammogram. $E_{\text {LUMO }}$ level of EE-1 was found to be $3.23 \mathrm{eV}$ and the $E_{\mathrm{LUMO}}$ level is suitable for efficient electron injection to conduction band of $\left(E_{\mathrm{LUMO}}\left(\mathrm{TiO}_{2}\right)=4.2 \mathrm{eV}\right)$. EE-1 dye comprising anchoring groups can inject electrons to the conduction band of $\mathrm{TiO}_{2}$ in organic dye sensitized solar cells. The photovoltaic data revealed a short circuit photocurrent density of $1.86 \mathrm{~mA} / \mathrm{cm}^{2}$, an open circuit voltage of $430 \mathrm{mV}$, and a fill factor of 0.63 , corresponding to an overall conversion efficiency of $0.53 \%$. Ground state optimization and HOMO and LUMO frontier orbitals of EE-1 were presented in Figure 1.

\section{Experimental Section}

2.1. Materials. Diphenylamine, 4-bromo-1,8-naphthalic anhydride, $\mathrm{t}-\mathrm{BuOK}$, and palladium acetate were purchased from Aldrich. $\mathrm{P}(\mathrm{t}-\mathrm{Bu})_{3}$ was supplied from Acros Organics. All solvents were of spectroscopic grade and were used without any further purification.

2.2. Materials Characterization. The UV-Vis absorption spectrum of synthesized dyes was recorded in an Analytic JENA $S$ 600. Cyclic voltammetry measurements of synthesized dye were taken by using CH-Instrument 660 B Model Potentiostat equipment. Dye sensitized solar cells were characterized by current-voltage $(I-V)$ measurement. All current-voltages $(I-V)$ were done under $100 \mathrm{~mW} / \mathrm{cm}^{2}$ light intensity and AM 1.5 conditions. $450 \mathrm{~W}$ Xenon light source (Oriel) was used to give an irradiance of various intensities. $J-V$ data collection was made using Keithley 2400 Source-Meter and LabView data acquisition software.

2.3. Procedure for Synthesis of $N, N^{\prime}$-Diphenylbenzene1,4-diamino-1,8-naphthalic Anhydride Derivative. $N, N^{\prime}$ Diphenylbenzene-1,4-diamino-1,8-naphthalic anhydride is synthesized according to the literature with some modifications [4]. The mixture of diphenylamine $(1.6 \mathrm{~g}$, $6.4 \mathrm{mmol})$ and 4-bromo-1,8-naphthalic anhydride $(3.3 \mathrm{~g}$, $12 \mathrm{mmol})$ in dry toluene $(30 \mathrm{~mL})$ was added to t-BuOK $(1.6 \mathrm{~g}$, $15 \mathrm{mmol}), \mathrm{P}(\mathrm{t}-\mathrm{Bu})_{3}(0.12 \mathrm{~g}, 0.5 \mathrm{mmol})$, and palladium acetate $(0.056 \mathrm{~g}, 0.25 \mathrm{mmol})$. The resulting mixture was heated to $120^{\circ} \mathrm{C}$ for $28 \mathrm{~h}$ and then cooled to room temperature. Then water $(40 \mathrm{~mL})$ and ethyl acetate $(40 \mathrm{~mL})$ were added to the mixture. The organic layer was separated from the aqueous layer, washed successively with water and brine solution, and dried over anhydrous magnesium sulfate. The crude product was further separated by column chromatography (Silicagel, $\mathrm{CH}_{2} \mathrm{Cl}_{2} / \mathrm{Hexane}$ a red solid $74 \%$ ).

$N, N^{\prime}$-Diphenylbenzene-1,4-diamino-1,8-naphthalic anhydride. Yield: 74\%. IR (KBr): $\mathrm{cm}^{-1}, 3051,1761,1708,1580$, $1564,1504,1485,1458,1391,1334,1305,1262,1221,1147,1167$, 1114, 1078, 1018, 998, 898, 876, 852, 828, 772, 722, 743, 694.

${ }^{1} \mathrm{H}$ NMR (400 MHz, $\left.\mathrm{CDCl}_{3}, \mathrm{TMS}\right):$ \& $8.51(\mathrm{dd}, 2 \mathrm{H}), 8.48$ (dd, 2H), $8.32(\mathrm{dd}, 2 \mathrm{H}), 7.6(\mathrm{t}, 2 \mathrm{H}), 7.34(\mathrm{~d}, 2 \mathrm{H}), 7.28(\mathrm{t}, 2 \mathrm{H})$, $7.08(\mathrm{~m}, 4 \mathrm{H}), 7.03(\mathrm{t}, 2 \mathrm{H}), 6.97(\mathrm{~m}, 4 \mathrm{H}), 6.93(\mathrm{t}, 2 \mathrm{H})$.

2.4. Fabrication of Dye Sensitized Solar Cell. The dye sensitized solar cell device fabrication starts with cleaning of the fluorine doped tin oxide (FTO) coated glass substrates in acetone and isopropanol by using an ultrasonic bath. FTO $\left(\mathrm{SnO}_{2}:\right.$ F, Pilkington TEC-15; $\left.R_{\text {sheet }}: 15 \mathrm{O} / \&\right)$, electrically conductive oxide-coated glass, was used as transparent electrode. $\mathrm{TiO}_{2}$ electrode consists of an adsorbent mesoporous layer with $20 \mathrm{~nm}$ anatase $\mathrm{TiO}_{2}$ particle size of $7 \mathrm{~mm}$ thickness and a second light scattering layer with $400 \mathrm{~nm}$ anatase $\mathrm{TiO}_{2}$ particle size of $5 \mathrm{~mm}$ thickness. Preparation and characterization of double-layer $\mathrm{TiO}_{2}$ electrode were previously described by Burfeindt et al. [25].

Dye solution was prepared in chlorobenzene $(1: 1)$ mixture with a concentration of $0.5 \mathrm{mM} \mathrm{N}, \mathrm{N}^{\prime}$ diphenylbenzene1,4-diamino-1,8-naphthalic anhydride (EE-1). $\mathrm{TiO}_{2}$-coated electrode, after sintering at $450^{\circ} \mathrm{C}$ for $30 \mathrm{~min}$ and cooling to $100^{\circ} \mathrm{C}$, was kept overnight in EE-1 solutions for adsorption. EE-1 adsorbed $\mathrm{TiO}_{2}$-coated glass was washed with pure chlorobenzene and dried in vacuum. Platinized FTO glass was used as a counter electrode. Platinization of counter electrode was done by coating of FTO glass with $1 \%$ solution of hydrogen hexachloroplatinate (Aldrich) in 2-propanol and annealing at $400^{\circ} \mathrm{C}$ for $30 \mathrm{~min}$. Cells were prepared in sandwich geometry. Surlyn-1702 (DuPont) frame was used as a spacer and a thermoplastic sealant between the two electrodes. Prepared cells were sealed by heating at $100^{\circ} \mathrm{C}$. Electrolyte was filled into the space created by Surlyn1702 between the electrodes under vacuum using a small hole predrilled on the counter electrode with the help of a diamond drill. After filling the electrolyte, a small hole was sealed again using a piece of Surlyn-1702 and a piece of cover glass. The electrolyte consisted of $0.6 \mathrm{M} \mathrm{N}$-methyl-N-butyl imidazolium iodide (BMII) + 0.1 M LiI + 0.05 M I2 + 0.5 M 4-tert-butyl pyridine (TBP) in acetonitrile. Active areas of the cells were adjusted to $0.159 \mathrm{~cm}^{2}$ with a special mask.

Dye sensitized solar cells were characterized by currentvoltage $(I-V)$ measurement. All current-voltages $(I-V)$ were 


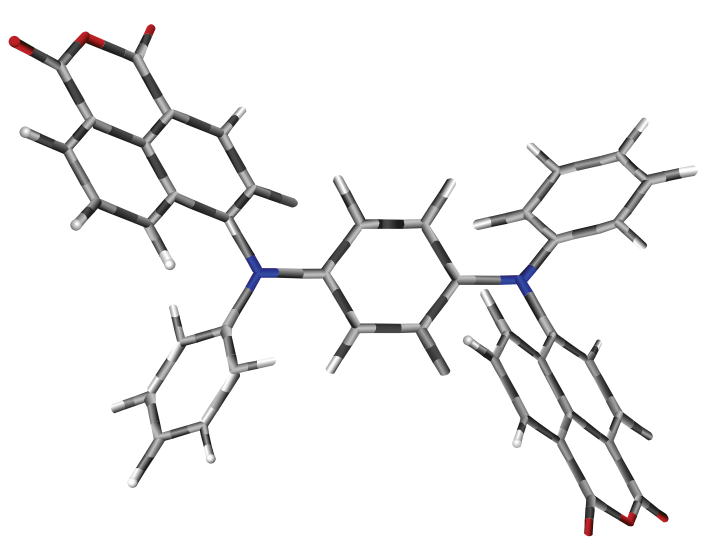

(a)

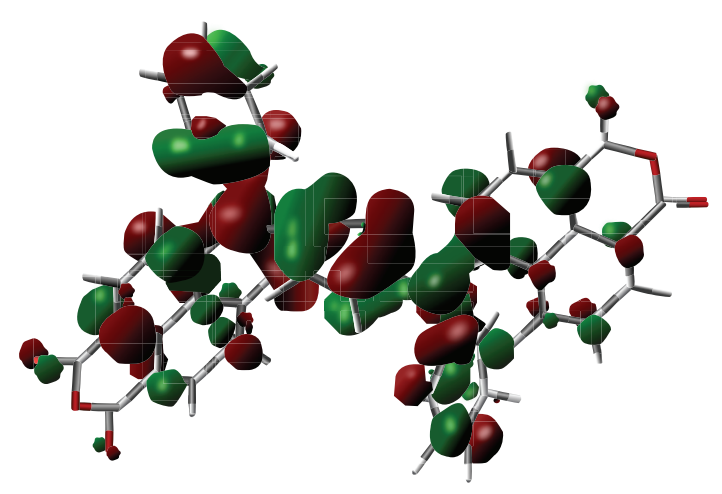

HOMO

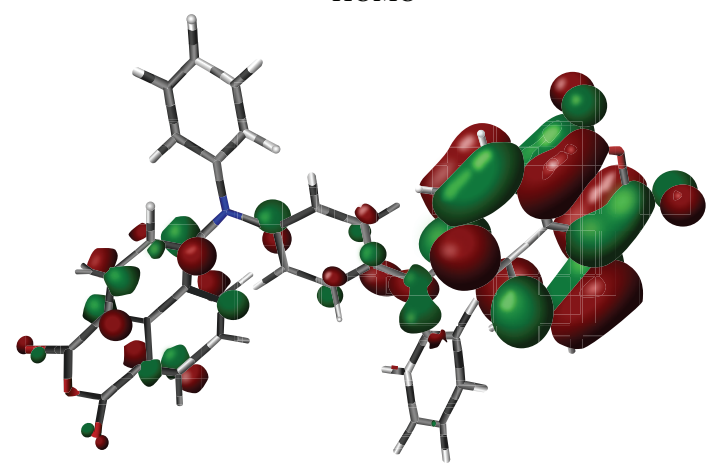

LUMO

(b)

FIGURE 1: Ground state optimization of EE-1 (a) and HOMO and LUMO frontier orbital of EE-1 (b).

done under $100 \mathrm{~mW} / \mathrm{cm}^{2}$ light intensity and AM 1.5 conditions. $450 \mathrm{~W}$ Xenon light source (Oriel) was used to give an irradiance of various intensities.

The spectral output of the lamp was matched in the region of 350-700 nm with the aid of Schott K113 Tempax sunlight filter. $I-V$ data collection was made by using Keithley 2400 Source-Meter and LabView data acquisition software. $I-V$ characteristics of dye sensitized solar cell in dark and under illumination are shown in Figure 5.

\section{Results and Discussion}

3.1. Absorption Spectrum of $N, N^{\prime}$-Diphenylbenzene-1,4diamino-1,8-naphthalic Anhydride Derivative. The main importance of organic dye in dye sensitized solar cell is to make absorption in visible region. 1,8-Naphthalic anhydride group is only absorbed in the UV region. If diphenyl amine group is condensed onto naphthalic anhydride group from 4 positions, a pronounced red shift is observed in the absorption spectrum because of bathochromic effect. Absorption is observed at $500 \mathrm{~nm}$ region and shifted up to $620 \mathrm{~nm}$ in Figure 1 for $\mathrm{N}, \mathrm{N}^{\prime}$-diphenylbenzene-1,4-diamino1,8-naphthalic anhydride. N, $\mathrm{N}^{\prime}$-Diphenyl benzene-1,4diamino-1,8-naphthalic anhydride is absorbed in the visible region and is a promising material for dye sensitized solar cell application.

3.2. $E_{\mathrm{HOMO}}$ and $E_{\mathrm{LUMO}}$ Values of $N, N^{\prime}$-Diphenylbenzene-1,4diamino-1,8-naphthalic Anhydride Derivative. $E_{\mathrm{HOMO}}$ and $E_{\text {LUMO }}$ values of $\mathrm{N}, \mathrm{N}^{\prime}$-diphenylbenzene-1,4-diamino-1,8naphthalic anhydride (EE-1) were calculated by using cyclic voltammograms (Figure 3). Solutions of EE-1 derivative were prepared in chloroform $\left(10^{-3} \mathrm{M}\right)$. A three-electrode cell was used consisting of glassy carbon working electrode, $\mathrm{Pt}$ wire counter electrode, and $\mathrm{Ag} / \mathrm{AgCl}$ reference electrode, all placed in a glass vessel. Tetrabutylammonium hexafluorophosphate $\left(\mathrm{TBAPF}_{6}\right), 0,1 \mathrm{M}$, was used as supporting electrolyte. Ferrocene was used as internal reference electrode. EE-1 derivative shows both reversible reduction and oxidation potential in Figure 2. In calculation, the zero vacuum level of ferrocene was taken as $4.8 \mathrm{eV}$ [19]. We used the following equation to calculate $E_{\mathrm{HOMO}}$ and $E_{\mathrm{LUMO}}$ energy levels of EE-1: $E_{\mathrm{LUMO}}=-e\left(E_{1 / 2 \text { (redox) }}-E_{\text {fer }}.\right)+4.8[19] . E_{\mathrm{HOMO}}$ and $E_{\mathrm{LUMO}}$ energy levels of EE-1 derivative were $5.06 \mathrm{eV}$ and $3.23 \mathrm{eV}$, respectively. $E_{\mathrm{HOMO}}$ and $E_{\mathrm{LUMO}}$ values of EE-1 are presented in Table 1. $E_{\text {LUMO }}$ value of EE-1 is higher than the conduction band of $\mathrm{TiO}_{2}, E_{\mathrm{CB}} \mathrm{TiO}_{2}=4.2 \mathrm{eV}$. Schematic energy diagram of the device fabricated using EE-1 dye was 


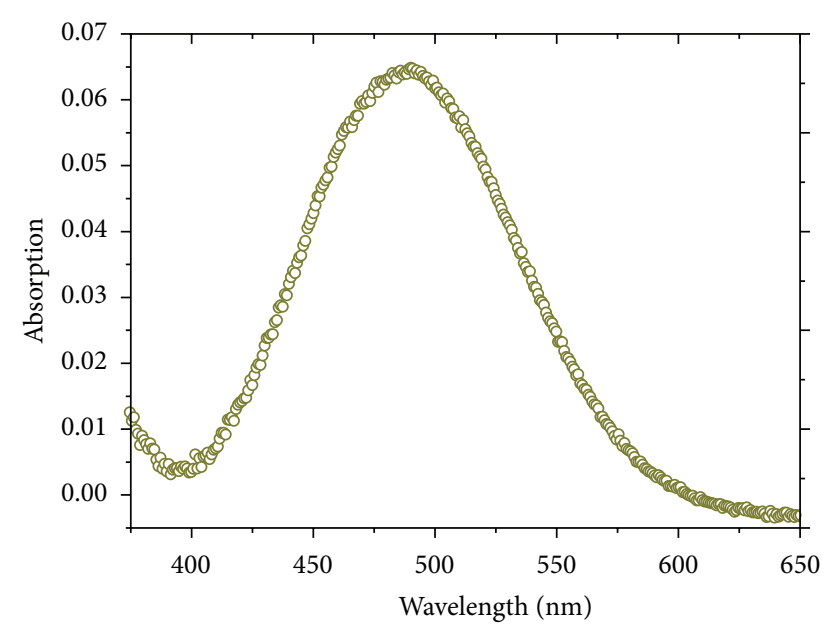

Figure 2: Absorption spectrum of $\mathrm{N}, \mathrm{N}^{\prime}$-diphenylbenzene-1,4diamino-1,8-naphthalic anhydride derivative.

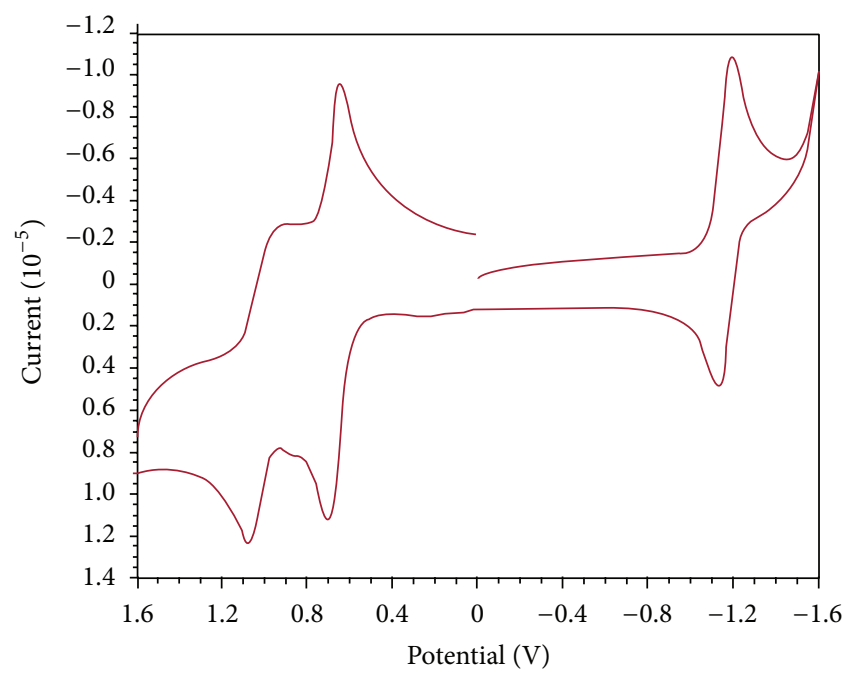

FIGURE 3: Cyclic voltammogram of $\mathrm{N}, \mathrm{N}^{\prime}$-diphenylbenzene-1,4diamino-1,8-naphthalic anhydride (EE-1).

TABLE 1: $E_{\mathrm{LUMO}}$ and $E_{\mathrm{HOMO}}$ energy levels of synthesized dye.

\begin{tabular}{ccccc}
\hline & $E_{\text {red }}$ & $E_{\text {ox }}$ & $E_{\text {HOMO }}$ & $E_{\text {LUMO }}$ \\
\hline EE-1 & -1.18 & 0.64 & 5.06 & 3.22 \\
\hline
\end{tabular}

$E_{\text {ferrocene }}=0.39 \mathrm{~V}$ (ferrocene is internal reference electrode).

$E_{\text {red }}=$ reduction potentials of synthesized derivative.

$E_{\mathrm{ox}}=$ oxidation potentials of synthesized derivative.

TABLE 2: Photovoltaic performances of DSSC.

\begin{tabular}{ccccc}
\hline & $J_{\mathrm{sc}}\left(\mathrm{mAcm}^{-2}\right)$ & $V_{\mathrm{oc}}(\mathrm{mV})$ & $\mathrm{FF}$ & $\eta(\%)$ \\
\hline EE-1 & 1.86 & 430 & 0.63 & 0.53
\end{tabular}

shown in Figure 4. EE-1 derivative was absorbed in the visible region and EE-1 dye can inject the electrons to the conduction band of $\mathrm{TiO}_{2}$. EE- 1 is promising material in the field of DSSC application. Schematic diagram was presented in Figure 4.

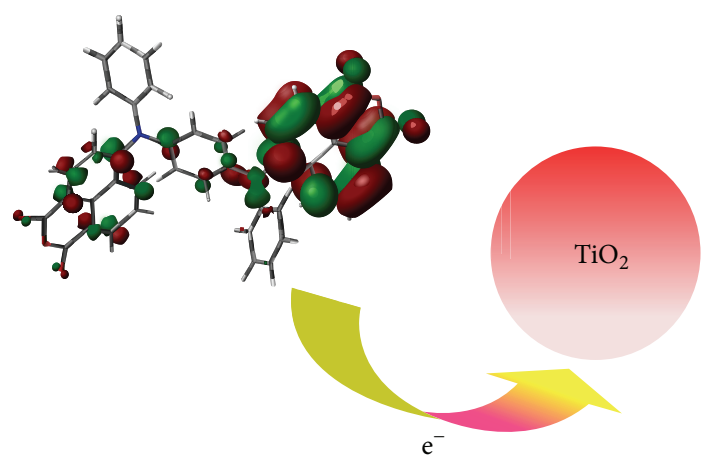

Figure 4: Schematic diagram of electron transfer from dye to $\mathrm{TiO}_{2}$.

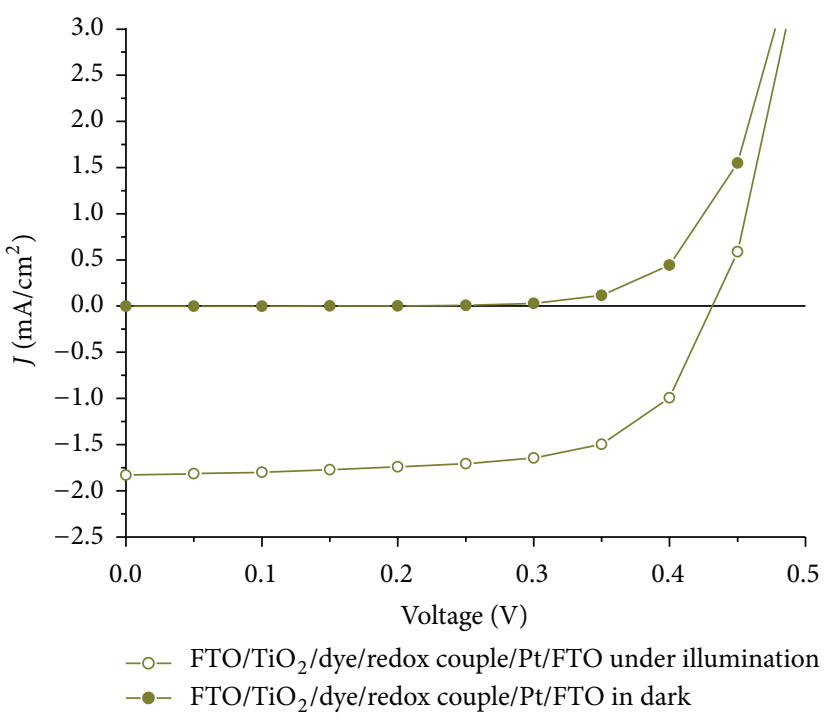

Figure 5: $I-V$ curve of the device "FTO/nc- $\mathrm{TiO}_{2} /$ conjugated naphthalene dye $(\mathrm{EE}-1) / \mathrm{I}^{-} / \mathrm{I}_{3}{ }^{-} / \mathrm{Pt} / \mathrm{FTO}$."

3.3. Photovoltaic Characterization. The current-voltage curve for DSSC based on conjugated naphthalene dye is shown in Figure 5 and Table 2. Under standard global AM 1.5 solar irradiation, the $\mathrm{TiO}_{2}$ solar cell sensitized with EE-1 gave a short circuit current density $\left(J_{\mathrm{sc}}\right)$ of $1.86 \mathrm{~mA} \mathrm{~cm}{ }^{-2}$, open circuit voltage $\left(V_{\text {oc }}\right)$ of $430 \mathrm{mV}$, and a fill factor of 0.63 , corresponding to an overall conversion efficiency $(\eta)$ of $0.53 \%$.

The entire energy conversion efficiency, $\eta$, is calculated by means of the following equations:

$$
\eta=\frac{V_{\mathrm{oc}} I_{\mathrm{sc}} \mathrm{FF}}{P_{\text {light }}} .
$$

Here, $V_{\mathrm{oc}}$ is open circuit voltage $(V), I_{\mathrm{sc}}$ is short circuit current $\left(\mathrm{mA} / \mathrm{cm}^{2}\right)$, and FF is fill factor and $P_{\text {light }}\left(\mathrm{mW} / \mathrm{cm}^{2}\right)$ :

$$
\mathrm{FF}=\frac{V_{\mathrm{max}} I_{\max }}{V_{\mathrm{oc}} I_{\mathrm{sc}}}
$$


where $V_{\max }$ and $I_{\max }$ are voltage and current at the point of maximum power output of cell.

Binding of the organic dye onto the $\mathrm{TiO}_{2}$ surface can take place via anhydride groups. According to the reports in the literature, six different adsorption modes can be seen between dye and metal oxide surfaces: (i) covalent bonding of dye onto the semiconductor surface, (ii) electrostatic interactions, (iii) hydrogen bonding, (iv) self-assembly, (v) physisorption of dye on the surface via van der Waals interactions, and (vi) physical entrapment $[26,27]$. For the EE-1 dye, covalent binding occurs between anhydride anchoring group and semiconductor surface would be more dominant compared to the others. And in the literature, it is proven that anhydride groups are attached to $\mathrm{TiO}_{2}$ surface in the dicarboxylic form. Carboxylic groups are the most important anchoring groups to attach to the surface of titanium dioxide. Anhydride groups are attached to titanium dioxide easily. In this context, the covalent binding taking place at the dye-semiconductor interface is very important. Theoretical calculations also showed that, in the LUMO level, electron densities were localised on the anhydride group. As a result of this effect, the dye binding onto the $\mathrm{TiO}_{2}$ surface can contribute to electron injection efficiently, and this leads to electron injection yield for $\mathrm{TiO}_{2}$ based DSSC.

\section{Conclusion}

We have molecularly engineered a novel type of organic sensitizer. By increasing the $\pi$-conjugation of the dye, the $E_{\text {HOMO }}$ and $E_{\text {LUMO }}$ energy levels were tuned, which was further supported by electrochemistry. Theoretical calculations showed that electron densities were localised on the anhydride group. When the dye excited to the LUMO level, efficient electron transfer will be to the conduction band of $\mathrm{TiO}_{2}$. Conjugated organic dye, which has aryl amine moiety as the electron donor and anhydride moiety as electron acceptor, showed good performance as photosensitizers in DSSCs. We obtained an overall conversion efficiency of $0.53 \%$ under AM 1.5 irradiation $\left(100 \mathrm{~mW} / \mathrm{cm}^{2}\right)$ with a DSSC based on EE-1 (short circuit photocurrent density of $1.86 \mathrm{~mA} / \mathrm{cm}^{2}$, an open circuit voltage of $430 \mathrm{mV}$, and a fill factor of 0.63 ).

\section{Conflict of Interests}

The author declares that there is no conflict of interests regarding the publication of this paper.

\section{Acknowledgments}

The author acknowledges the project support funds of Research Fund Center of Ege University (AFS) (EBILTEM), Scientific Research Council of Turkey (TUBITAK), the State Planning Organization of Turkey (DPT), and Alexander von Humboldt foundation of Germany. The author thanks Cagatay ELA for proofreading.

\section{References}

[1] B. O’Regan and M. Grätzel, "A low-cost, high-efficiency solar cell based on dye-sensitized colloidal $\mathrm{TiO}_{2}$ films," Nature, vol. 353, pp. 737-740, 1991.

[2] M. Grätzel, "Dye-sensitized solar cells," Journal of Photochemistry and Photobiology C, vol. 4, no. 2, pp. 145-153, 2003.

[3] N.-G. Park and K. Kim, "Transparent solar cells based on dye-sensitized nanocrystalline semiconductors," Physica Status Solidi (A), vol. 205, no. 8, pp. 1895-1904, 2008.

[4] S. Erten-Ela, J. Brendel, and M. Thelakkat, "Solid-state dyesensitized solar cells fabricated with nanoporous $\mathrm{TiO}_{2}$ and TPD dyes: analysis of penetration behavior and I-V characteristics," Chemical Physics Letters, vol. 510, no. 1-3, pp. 93-98, 2011.

[5] A. Hagfeldt and M. Grätzel, "Molecular photovoltaics," Accounts of Chemical Research, vol. 33, no. 5, pp. 269-277, 2000.

[6] M. Grätzel, "Photoelectrochemical cells," Nature, vol. 414, no. 6861, pp. 338-344, 2001.

[7] M. Grätzel, "Molecular photovoltaics that mimic photosynthesis," Pure and Applied Chemistry, vol. 73, no. 3, pp. 459-467, 2001.

[8] D. F. Watsonson and G. Meyer, "Electron injection at dyesensitized semiconductor electrodes," Annual Review of Physical Chemistry, vol. 56, pp. 119-156, 2005.

[9] N. A. Anderson and T. Lian, "Ultrafast electron transfer at the molecule-semiconductor nanoparticle interface," Annual Review of Physical Chemistry, vol. 56, pp. 491-519, 2005.

[10] N. S. Lewis, "Chemical control of charge transfer and recombination at semiconductor photoelectrode surfaces," Inorganic Chemistry, vol. 44, no. 20, pp. 6900-6911, 2005.

[11] A. B. F. Martinson, J. W. Elam, J. T. Hupp, and M. J. Pellin, "ZnO nanotube based dye-sensitized solar cells," Nano Letters, vol. 7, no. 8, pp. 2183-2187, 2007.

[12] J. Xia, N. Masaki, K. Jiang, and S. Yanagida, " $\mathrm{Nb}_{2} \mathrm{O}_{5}$ as a novel blocking layer at conducting glass $/ \mathrm{TiO}_{2}$ interfaces in dye-sensitized ionic liquid solar cells," The Journal of Physical Chemistry C, vol. 111, no. 22, pp. 8092-8097, 2007.

[13] Y. Wang, K. Yang, S.-C. Kim, R. Nagarajan, L. A. Samuelson, and J. Kumar, "In situ polymerized carboxylated diacetylene as a hole conductor in solid-state dye-sensitized solar cells," Chemistry of Materials, vol. 18, no. 18, pp. 4215-4217, 2006.

[14] M. Ikegami, K. Teshima, K. Miyoshi et al., "Platinum/titanium bilayer deposited on polymer film as efficient counter electrodes for plastic dye-sensitized solar cells," Applied Physics Letters, vol. 90, no. 15, Article ID 153122, 2007.

[15] N. Robertson, "Optimizing dyes for dye-sensitized solar cells," Angewandte Chemie-International Edition, vol. 45, no. 15, pp. 2338-2345, 2006.

[16] K. Hara, T. Sato, R. Katoh et al., "Molecular design of coumarin dyes for efficient dye-sensitized solar cells," The Journal of Physical Chemistry B, vol. 107, no. 2, pp. 597-606, 2003.

[17] T. Horiuchi, H. Miura, K. Sumioka, and S. Uchida, "High efficiency of dye-sensitized solar cells based on metal-free indoline dyes," Journal of the American Chemical Society, vol. 126, no. 39, pp. 12218-12219, 2004.

[18] E. Galoppini, "Linkers for anchoring sensitizers to semiconductor nanoparticles," Coordination Chemistry Reviews, vol. 248, no. 13-14, pp. 1283-1297, 2004.

[19] G. Ramakrishna, S. Verma, D. A. Jose et al., "Interfacial electron transfer between the photoexcited porphyrin molecule and $\mathrm{TiO}_{2}$ nanoparticles: effect of catecholate binding," The Journal of Physical Chemistry B, vol. 110, no. 18, pp. 9012-9021, 2006. 
[20] S. Altobello, C. A. Bignozzi, S. Caramori et al., "Sensitization of $\mathrm{TiO}_{2}$ with ruthenium complexes containing boronic acid functions," Journal of Photochemistry and Photobiology A, vol. 166, no. 1-3, pp. 91-98, 2004.

[21] C. C. Clark, G. J. Meyer, Q. Wei, and E. Galoppini, “Tuning open circuit photovoltages with tripodal sensitizers," The Journal of Physical Chemistry B, vol. 110, no. 23, pp. 11044-11046, 2006.

[22] P. Wang, C. Klein, J.-E. Moser et al., "Amphiphilic ruthenium sensitizer with $4,4^{\prime}$-diphosphonic acid-2, $2^{\prime}$-bipyridine as anchoring ligand for nanocrystalline dye sensitized solar cells," The Journal of Physical Chemistry B, vol. 108, no. 45, pp. 1755317559, 2004.

[23] D. Liu, R. W. Fessenden, G. L. Hug, and P. V. Kamat, "Dye capped semiconductor nanoclusters. Role of back electron transfer in the photosensitization of $\mathrm{SnO}_{2}$ nanocrystallites with cresyl violet aggregates,' The Journal of Physical Chemistry B, vol. 101, no. 14, pp. 2583-2590, 1997.

[24] M. K. Nazeeruddin, A. Kay, I. Rodicio et al., "Conversion of light to electricity by cis- $\mathrm{X}_{2}$ bis $\left(2,2^{\prime}\right.$-bipyridyl- $4,4^{\prime}$ dicarboxylate)ruthenium(II) charge-transfer sensitizers (X = $\mathrm{Cl}^{-}, \mathrm{Br}^{-}, \mathrm{I}^{-}, \mathrm{CN}^{-}$, and $\mathrm{SCN}^{-}$) on nanocrystalline $\mathrm{TiO}_{2}$ electrodes," Journal of the American Chemical Society, vol. 115, no. 14, pp. 6382-6390, 1993.

[25] B. Burfeindt, T. Hannappel, W. Storck, and F. Willig, "Measurement of temperature-independent femtosecond interfacial electron transfer from an anchored molecular electron donor to a semiconductor as acceptor," Journal of Physical Chemistry, vol. 100, no. 41, pp. 16463-16465, 1996.

[26] K. Kalyanasundaram and M. Grätzel, "Applications of functionalized transition metal complexes in photonic and optoelectronic devices," Coordination Chemistry Reviews, vol. 177, no. 1, pp. 347-414, 1998.

[27] S. Agrawal, N. J. English, K. Ravindranathan Thampi, and J. M. D. MacElroy, "Perspectives on ab initio molecular simulation of excited-state properties of organic dye molecules in dyesensitised solar cells," Physical Chemistry Chemical Physics, vol. 14, no. 35, pp. 12044-12056, 2012. 

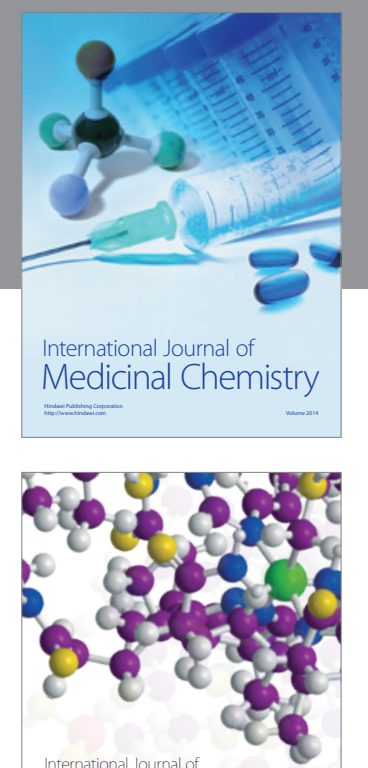

\section{Carbohydrate} Chemistry

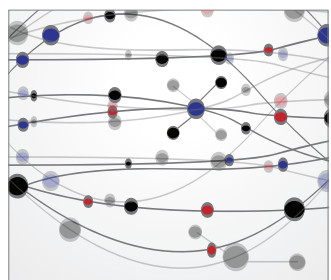

The Scientific World Journal
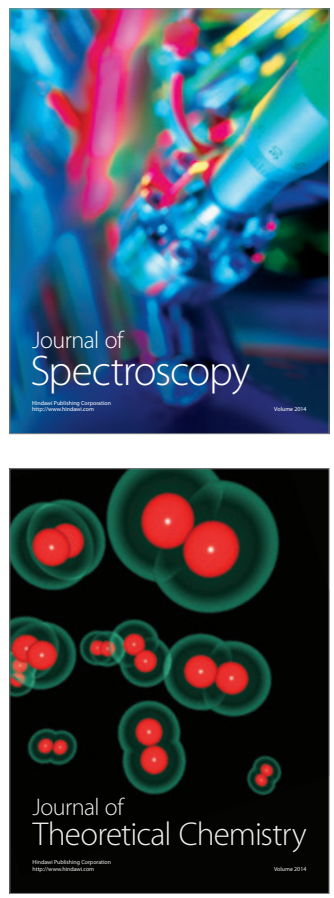
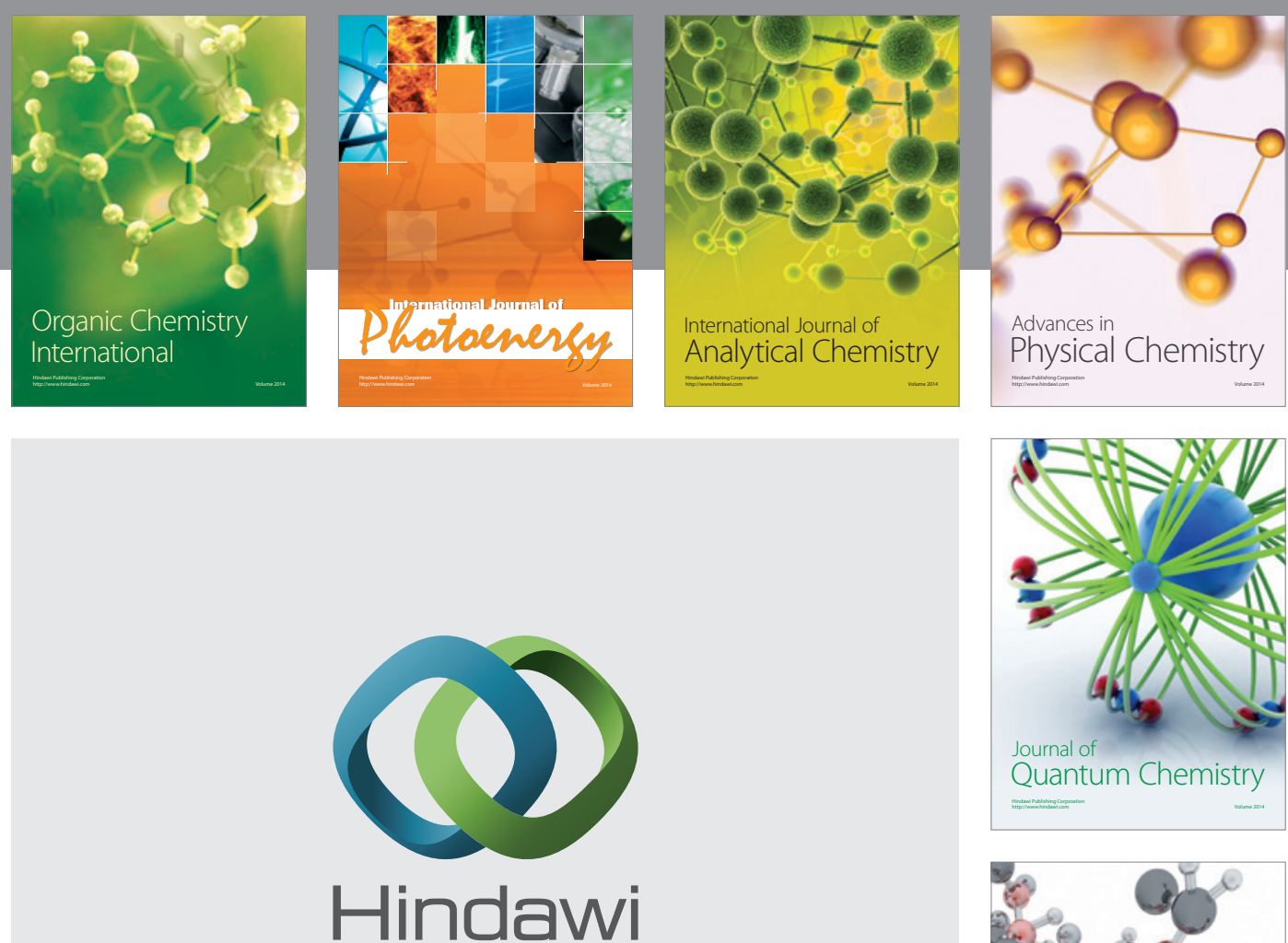

Submit your manuscripts at

http://www.hindawi.com

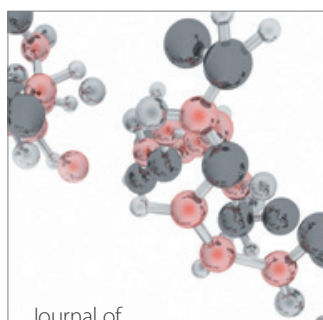

Analytical Methods

in Chemistry

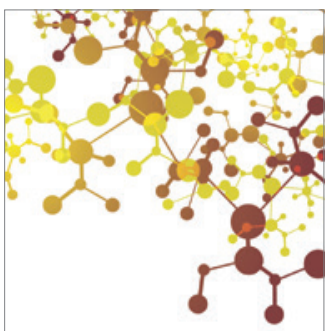

Journal of

Applied Chemistry

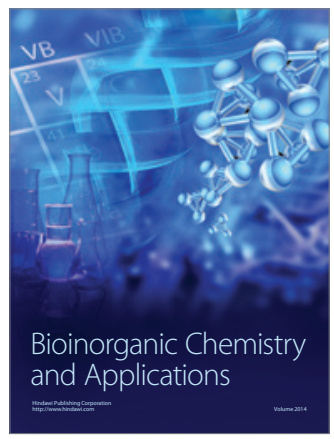

Inorganic Chemistry
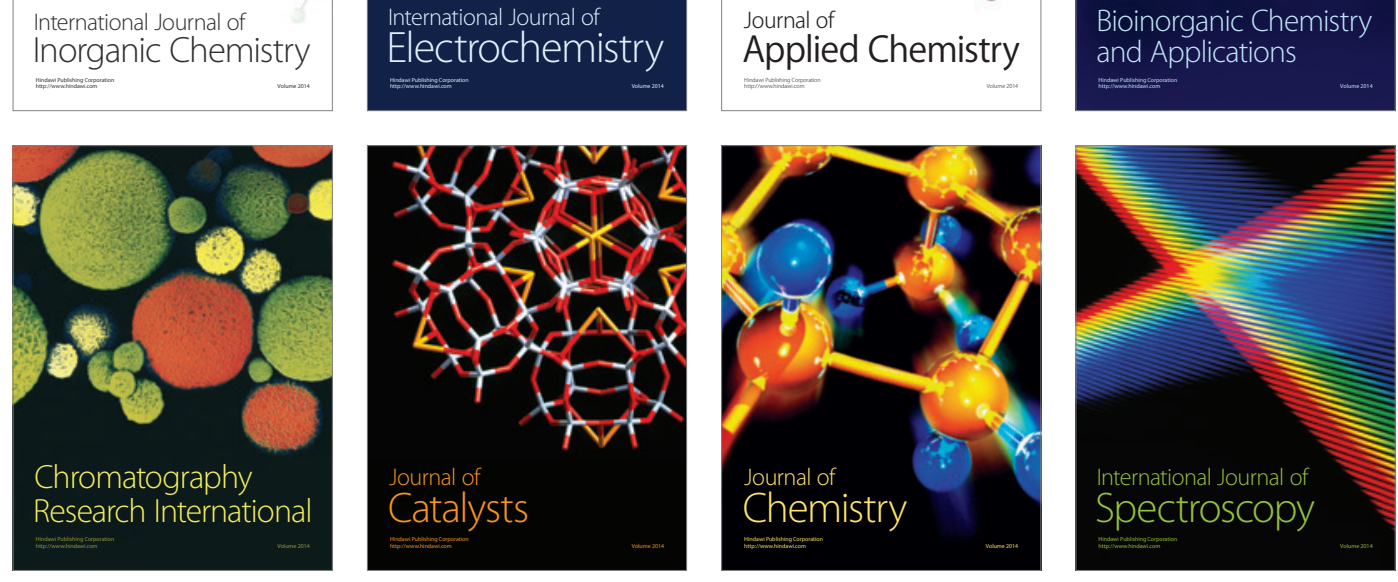